\title{
FAMILY BUSINESS INTERESTS UNDER THE MATRIMONIAL PROPERTY AND COMPANIES LEGISLATION - AN INTRODUCTION
}

\author{
Virginia Grainer and Bob Dugan*
}

This article is a preliminary investigation of family business interests under the Matrimonial property Act 1976 and the Companies Act 1993. Many of the issues raised in this introductory study will be developed further in a forthcoming work. ${ }^{1}$

\section{INTRODUCTION}

The Companies Act 1993 [CA] and Matrimonial Property Act 1976 [MPA] are the proverbial two ships passing in the night. Whilst small businesses in the form of one and two person companies comprise around $90 \%$ of the over 300,000 registrations under the CA, the statute was designed for widely held entities. It accommodates closely held family companies only by way of isolated exceptions. The peculiar deferred property regime and sharing rules of the MPA reflect, on the most generous view, a family structure where one spouse owns and husbands the wealth and the other manages the household. This paradigm intersects reality for an increasingly insignificant number of families and certainly not for many participants in the steady stream of cases under the MPA involving family businesses. In view of these legislative cross purposes, it is hardly surprising to find that so many disputes under the MPA arise from inadequately planned transactions, are resolved on insufficient argument and evidence, and generate conflicting case law. This article introduces the reader to the interrelationship of the matrimonial property regime and the legislative regulation of business entities. As its principal focus, the article explores the implications of the MPA for the choice of entity, source of finance, division of shares and allocation of management responsibility.

* Deputy Dean and Senior Lecturer in Law, Victoria University of Wellington and Reader in Law, Victoria University of Wellington.

1 "Husband and Wife companies < $\underline{w w w . v u w . a c . n z / \sim \text { dugan1 }}>$. 


\section{A Business Interests Under the MPA}

\section{Overview of the MPA}

The Matrimonial Property Act 1976 [MPA] is a deferred community property regime. Section 19 provides that, until the property is divided, each spouse is free to acquire, deal with or dispose of any property as if the Act had not been passed. This means that one spouse can acquire an interest in the other spouse's property only by gift, purchase or operation of law. The situation changes on separation. All the property belonging to the spouses individually or jointly is, eo ipso, catagorised under sections 8-10 as matrimonial property or separate property. Each spouse retains their separate property and under section 15(1) is presumptively entitled to one half of the matrimonial property unless their contribution to the marriage has been clearly greater than that of the other spouse. Section 18 weights equally monetary and non-monetary contributions. Matrimonial property is defined in section 8 by a list of twelve types of property including, as the practically most important category, all property acquired by either spouse after the marriage. Separate property is defined generally in section 9(1) as all property of either spouse which is not matrimonial property. Separate property extends under section 9(2) to property acquired out of separate property and the proceeds of any disposition of separate property. Property acquired by succession or by survivorship or as a beneficiary under a trust or by gift qualifies as separate property under section 10(1) unless intermingled with matrimonial property. Section 10(2) provides that interspousal gifts constitute separate property unless used for the benefit of both spouses. Under section 9(3), an increase in value of separate property as well as any income or gains from such property are also separate property unless attributable, wholly or in part, to the actions of the other spouse or the application of matrimonial property, in which event the increase or income qualifies as matrimonial property subject to the presumptive equal sharing rule. Section 21 allows the spouses to contract out of the Act either in contemplation of marriage or after marriage. The agreement must be in writing signed by both parties after receiving independent legal advice.

\section{The deferred nature of matrimonial property}

The most significant implications of the MPA for planning a family business relate to the deferred nature of the matrimonial property interest. Until separation or the threat of separation, the interest amounts to little more than an expectancy. It confers none of the control powers which gives legal property interests their value and exclusionary features. This is aptly illustrated by an example which does not involve a business entity.

Example. $\mathrm{H}$ and $\mathrm{W}$ are married. $\mathrm{H}$ is engaged in full-time employment and $\mathrm{W}$ manages the household. $\mathrm{H}$ and $\mathrm{W}$ propose to purchase a rental property. The purchase will be financed 
$5 \%$ by savings from H's salary and the remainder by a bank loan secured by a first mortgage over the property. The couple are concerned to know how to take title to the asset.

The property can be titled in the name of one of the spouses, as a joint tenancy, as a tenancy in common or as a joint tenancy with right of survivorship. No matter how title is taken, in the absence of an agreement under MPA section 21 the investment qualifies as matrimonial property as it is acquired after marriage and is not the identifiable proceeds of separate property.

\section{Inchoate interest subject to defeasance}

Where matrimonial property is titled in the name of one spouse, their dispositions and encumbrances will defeat the other spouse's inchoate matrimonial property interest.

Example. Suppose that the property in the previous example is titled in the name of H. Ten years later, in need of funds for the business, $\mathrm{H}$ borrows $\$ 50,000$ from the bank and secures the loan by the existing mortgage. Two years later, both the business and the marriage collapse.

Under MPA section 20, the bank's security will take priority over the wife's matrimonial property interest. The $\$ 50,000$ secured loan will reduce by $\$ 25,000$ the amount to which $\mathrm{W}$ would otherwise have been entitled pursuant to the equal sharing rule. As the business is a family one, W will not qualify for an order under section 20(6) increasing her share of the matrimonial property. Further, apart from informal measures, there is nothing $\mathrm{W}$ could have done at the time to prevent $\mathrm{H}$ from encumbering the property as it was titled in $\mathrm{H}$ 's name. To protect her inchoate matrimonial property interest, $\mathrm{W}$ must obtain a present legal entitlement which enables her to control the disposition of the asset. The entitlement can be implemented as a property interest or as a contract right. In the circumstances, a joint tenancy arrangement would be the obvious solution.

\section{Ownership interests in business entities}

The lesson of the previous example also holds true where the property is a business.

Example. $\mathrm{H}$ and $\mathrm{W}$ are married. The family's assets comprise a home and a savings account. $\mathrm{H}$ proposes to start a business. The start up capital will be provided by the family's savings and a bank loan secured by the existing mortgage over the family home.

The business can be organised as the sole proprietorship of one of the spouses, as a one person company, as a two person company or as a partnership. The choice of entity determines the type of property which is subject to the MPA. Consider first the case where the business is operated as a sole proprietorship by H. Even though all the business assets will be held in H's name, they will, in the event of separation, constitute matrimonial property subject to the presumptive equal sharing rule. However, until that time, the assets are H's legal property and he is free to use and dispose of them as he sees fit. The 
value of W's inchoate matrimonial property depends on H's disposition and management of the assets, matters outside her legal control.

\section{The one person company}

The situation is not appreciably different where the business is organised as a one person company with $\mathrm{H}$ holding all the shares. Here, the property rights in the business assets are owned exclusively by the company. Shareholders have no rights in their company's property except such as they may acquire under contracts for sale and purchase, lease or security. H's shares in the company, as they were acquired after marriage, are the matrimonial property. In the event of separation, each spouse is presumptively entitled to one half the shares. However, as the shares are the property of $\mathrm{H}$, until separation he is free to dispose of them as he sees fit. By selling or pledging the shares, $\mathrm{H}$ can undermine W's matrimonial property expectancy. More importantly, as owner of the shares, $\mathrm{H}$ has exclusive control over management of the company which, in turn, owns the assets. Mismanagement of the company will diminish the value of the company assets and therewith also the value of the company shares which comprise the potential matrimonial property.

\section{No protection under proposed section $44 F$}

This risk lies outside the protective scope of proposed section $44 \mathrm{~F}^{2}$ which authorises the Court to make compensatory orders where matrimonial property has been transferred to a qualifying company, that is, one in which one spouse owns at least half the shares. The provision applies only where the disposition has the effect of defeating the claim or rights of the other spouse. In situations of concern in this article, the initial disposition of matrimonial property is for equivalent value, that is, the matrimonial property is exchanged for shares of even value. The diminution of the value of the other spouse's matrimonial property interest results from subsequent management of the company and exogenous economic factors.

\section{The two person company}

If the business is organised as a company with $\mathrm{H}$ and $\mathrm{W}$ as the shareholders, then all the shares will, irrespective of their allocation between the spouses, comprise matrimonial property. This is subject to certain qualifications respecting interspousal gifts discussed below. Nor does W's ownership of some of the shares alter the fact that all the business assets, which underlie the value of the shares, belong exclusively to the company. The significance of W's ownership lies primarily in the control conferred by her shares, the extent of which depends on the size of the holding. For instance, under CA section 129, a

2 Matrimonial Property Amendment Bill 1998, cl 47. 
holding greater than $25 \%$ provides $\mathrm{W}$ negative control over major transactions, that is, ones involving amounts in excess of the greater part of the company's assets.

\section{The partnership}

Organisation of the business as a partnership between $\mathrm{H}$ and $\mathrm{W}$ results in a complex property regime which reflects the fact that the partnership is not a legal entity in all respects. Unlike a company or individual, the partnership cannot hold all the property interests in an asset. Legal title can vest in the partnership but an equitable interest remains with the partners. This equitable interest is not freely alienable and can be realised only in a winding up. ${ }^{3}$ Despite its evanescent nature, the partner's interest in partnership assets was held in Maw $v$ Maw to constitute property for purposes of the MPA. ${ }^{4}$ Accordingly, use of the partnership structure gives rise to two distinct types of potential matrimonial property. On formation of the partnership, $\mathrm{H}$ and $\mathrm{W}$ acquire legal title to their partnership shares, the counterpart to company shares. These shares will, irrespective of their allocation, comprise matrimonial property subject to the presumptive equal sharing rule. Like company shares, the partnership shares provide their holder with control over the management of the partnership assets and therewith control over the value of the matrimonial property. In addition, each partner spouse also has an equitable Maw interest in every asset acquired by the firm. This interest also qualifies as matrimonial property subject to the equal sharing rule.

\section{Summary}

No matter how legal entitlements are configured - that is, whether as individual ownership, joint ownership or corporate ownership-operating assets or derivative assets [shares] qualify as matrimonial property subject to the presumptive equal sharing rule. However, until separation, a spouse's matrimonial property interest is inchoate and subordinate to legal ownership. Where $\mathrm{H}$ holds the exclusive legal entitlement to the operating or derivative assets, W's matrimonial property expectancy is at his mercy. To protect her expectancy, $\mathrm{W}$ must obtain a control entitlement over the operating and/or derivative assets.

\section{B Control Mechanisms in the Company Entity}

\section{Shares as matrimonial property and their value}

In most situations, the company will be the preferred vehicle for ownership and operation of the family business. As its principal advantages, the company form protects

3 Partnership Act 1908, ss 23(2) 34.

4 Maw v Maw [1981] 1 NZLR 25, 29-30 (CA). 
the spouses from liability for at least some business debts and permits the creation of a registered charge as security for borrowings. A spouse's matrimonial property interest will attach, if at all, only to the shares in the company, the value of which depends upon the management of the business.

Example. The family business is owned and operated by a company whose balance sheet shows assets of $\$ 1 \mathrm{~m}$ represented by liabilities of $\$ 0.8 \mathrm{~m}$ and shareholder funds of $\$ 0.2 \mathrm{~m}$. The shares are all held by $\mathrm{H}$. $\mathrm{H}$ proposes that the company purchase an income producing property for $\$ 0.2 \mathrm{~m}$ to be financed $10 \%$ out of company funds and $90 \%$ by a loan secured by the purchased property.

This transaction impacts significantly on the potential value of the shares. For instance, if the property is worth only $\$ 100,000$ or falls to that value, this halves the net assets of the firm which comprise the basis for the value of the matrimonial property shares. Other common transactions capable of affecting the value of the shares include the payment of dividends and other distributions, the issue of shares for non-cash assets, changes in management personnel and sale of the undertaking. The value of the matrimonial property shares lies largely within the control of the party or parties responsible for the initiation and terms of these transactions. Whilst the company is one of the two parties to the specific transaction, it is not, as a juristic entity, in control of the transaction except in a strictly formal sense. Control resides with individuals who authorise the transactions and act on behalf of the company.

\section{Choice of control mechanism}

There are several ways to implement control over transactions of a company under the CA. As a threshold matter, it is useful to distinguish between negative control and positive control. A person with positive control has the power to initiate and implement a transaction, whilst a person with negative control has power to block a transaction. Suppose that $\mathrm{W}$ seeks control over transactions that would qualify as major transactions under CA section 129, that is, ones involving amounts greater than half the value of the company's assets. There are four obvious ways to implement this control:

1 Allocation of shares. As major transactions require special resolution approval, any holding greater than $25 \%$ gives $\mathrm{W}$ negative control.

2 Position on board. As sole director, $\mathrm{W}$ has positive control over the initiation of such a transaction under section 128; as co-director, she has negative control over board resolutions under the Third Schedule.

3 Constitution. Though she be neither a director nor a shareholder, $\mathrm{W}$ can exercise control over a major transaction through an appropriate approvals clause in the company constitution. 
4 Side agreement. The approvals clause can be contained in an agreement between $\mathrm{W}$ and the company rather than in the constitution.

Whilst each of the measures provides the desired control, there are ramifications which, depending on the situation, make one measure more or less desirable than the others.

\section{Ramifications}

A position on the board and an allocation of shares will carry control powers in addition to the particular one sought by $\mathrm{W}$. As co-director, $\mathrm{W}$ has negative control over virtually all aspects of the company's operation. A $26 \%$ parcel confers negative control over all matters requiring unanimous or special resolution approval. On the other hand, as director, $\mathrm{W}$ becomes liable for the performance of a wide range of general, transactionspecific and ministerial obligations, the breach of which attracts both criminal and civil liability. The approvals clause, whether contained in a side agreement or the constitution, makes W a deemed director under the Companies Act section 126 in respect of the transactions in question. In contrast, she can exercise the control powers associated with a $26 \%$ parcel without becoming a deemed director. When placed in the constitution, the approvals clause provides $\mathrm{W}$ negative control over section 107 assents but, unlike a side agreement, is a matter of public record. Whilst approvals clauses are commonly used by unrelated business people, they are easily perceived as inconsistent with the trust and communality associated with the marital relationship. In contrast, an allocation of shares will frequently involve a gift which is far more compatible with the marital relationship.

\section{$4 \quad 50: 50$ split with both spouses on the board as optimal}

In a sample of new registrations under the CA, the most common husband/wife company is one in which the spouses hold an equal number of shares and serve as codirectors of the business. This is an optimal control situation in several respects. First, as co-director, each spouse has negative control over all management decisions. Secondly, where named as initial director in the application for registration, each spouse is entrenched on the board under the Companies Act section 156. Thirdly, each spouse has legal ownership and control over half the matrimonial property shares. Fourthly, as the equal division of shares and board positions track the formal and informal communality of the marital relationship, it can often be achieved without either party perceiving themselves disadvantaged. Finally, the configuration is economical in terms of transaction costs. Based on the statutory regime, it can be implemented without a company constitution through the appropriate completion of the application for registration. Whilst the position of director should not be lightly assumed, the CA provides safe harbour strategies which reduce liability exposure. A 50\% holding unaccompanied by a position on the board leaves $\mathrm{W}$ with negative control over appointments to the board and matters requiring special or unanimous resolution approval, for example, major transactions and 
relief from the audit requirement. Further, a new issue of shares will reduce W's holding below $50 \%$ where $\mathrm{W}$ cannot afford to exercise the pre-emptive right under section 45 .

\section{Implementation of the Share Allocation}

\section{Implementation of the allocation}

Whenever a division of shares is chosen as a control measure, the adviser must consider how the allocation will be implemented and the consequences under the MPA. These are far from trivial in even common situations.

Example. H incorporates a business with an initial capital of $\$ 40,000$ drawn from an account in H's name and funded with the savings from H's full time employment. W is engaged full time in the management of the couple's home and care of their children.

Whilst the account qualifies as matrimonial property, owner $\mathrm{H}$ can dispose of it without W's consent. This would also be true where the account was held in joint name and, as usual, each spouse had separate drawing authority. An allocation of shares will provide W control, the extent of which depends upon the size of her holding, over the risks which the investment poses for her inchoate matrimonial property interest. Unless $W$ has available separate property, she must acquire her shares by gift or with borrowed funds. Gift and debt finance are considered in this section and separate property finance in the next.

\section{Gift}

In situations like the previous example, it is common for $\mathrm{W}$ to receive her shares as a gift. There are a number of alternatives:

- $\mathrm{H}$ gives $\$ 20,000$ to $\mathrm{W}$. $\mathrm{W}$ uses the funds to subscribe for half the shares in the company.

- All the shares are issued to $\mathrm{H}$ for $\$ 40,000$. $\mathrm{H}$ then gives half the shares to $\mathrm{W}$.

- H makes $\mathrm{W}$ a co-owner of the savings account. Then $\mathrm{H}$ and $\mathrm{W}$ each subscribe for half the shares in the company and pay for them with drawings from the account.

- All the shares are issued to $\mathrm{H}$ for $\$ 40,000$. $\mathrm{H}$ then enters his and W's names in the share register as joint owners of all the shares.

Under each of these alternatives, $W$ receives her share interest as a gift from $\mathrm{H}$. This triggers MPA section 10 which provides that an interspousal gifts is separate property unless it is used for the benefit of both spouses. 


\section{Unexpected consequences}

The classification of W's shares as separate property may lead to results not anticipated by the parties.

Example. The business in the previous example is a success. By the time of separation, the shares have trebled in value from $\$ 40,000$ to $\$ 120,000$.

If all the shares qualify as matrimonial property, $\mathrm{H}$ and $\mathrm{W}$ are each presumptively entitled to $\$ 60,000$. However, if $W^{\prime}$ s $50 \%$ parcel qualifies as separate property, $\mathrm{W}$ will be presumptively entitled to $\$ 90,000$. This comprises $\$ 60,000$ representing her separate property shares plus $\$ 30,000$ representing half of the value of H's shares which qualify as matrimonial property. $H$ will be presumptively entitled to only $\$ 30,000$. Under the circumstances, it is unlikely that this allocation accords with the initial expectations of the parties or that intended by the drafters of the Act. The rule in section 10 makes sense for gifts of jewellery but not necessarily for the shares issued in the example.

\section{Result partially mitigated by sharing rules}

The unanticipated outcome can be partially mitigated by various provisos to the sharing rules. For instance, MPA section 9(3) provides that the increase in the value of W's shares is separate property unless attributable, wholly or in part, to the actions of $\mathrm{H}$ or the application of matrimonial property. Where $\mathrm{H}$ is the sole director or a co-director of the company, he can argue that the increase in value was attributable, at least in part, to his efforts. Even if only partially attributed, the entire increase becomes matrimonial property subject to the equal sharing rule. This will increase the matrimonial property associated with the business to $\$ 100,000$ comprised of H's shares $(\$ 60,000)$ and the increase in value of W's shares $(\$ 40,000)$. On separation, $H$ would be presumptively entitled to $\$ 50,000$. To eliminate the remaining $\$ 20,000$ disparity, $\mathrm{H}$ would have to prevail with the more difficult argument under section 18 that he had made a clearly greater contribution to the marriage partnership or seek relief under section 17(2) for sustaining the value of W's separate property.

\section{Gifted property used for joint benefit}

$\mathrm{H}$ can also invoke the qualification in MPA section 10(2) pursuant to which the interspousal gift qualifies as matrimonial property if used for the benefit of both husband and wife. However, in the example, the operation of the proviso is not free from doubt. In the event of separation, $\mathrm{W}$ will argue that the gift of shares was intended for her benefit, that is, to enable her to protect the value of her inchoate matrimonial property interest. $\mathrm{H}$ will, of course, take the position that $\mathrm{W}$ is adequately protected by having legal ownership of matrimonial property shares. To the extent that use for joint benefit turns on the parties' intention, the terms of the gift document can determine the effect of the proviso. For 
instance, the document could provide that the gift is expressly made for the benefit of both spouses by providing the basis for their joint participation in the management of the business. The question arises whether such a gift document constitutes a section 21 agreement.

\section{Debt financed shares}

Where $\mathrm{W}$ cannot fund her shares with separate property, the only alternative to a gift is a financed acquisition. The necessary credit can be provided by $\mathrm{H}$ or by the company. Two possibilities come to mind.

- $\quad H$ lends W $\$ 20,000$ which she uses to pay for the shares.

- W subscribes for half the shares under an agreement which leaves the subscription price unpaid until called by the board.

The use of company finance carries the obvious risk of liability in the event of liquidation. Also, as discussed elsewhere by one of the authors, the issue of unpaid shares gives rise to a variety of problems arising under part VI of the Companies Act. ${ }^{5}$ However, the debt incurred by $\mathrm{W}$ would not appear to pose a problem in the event of separation. Whether the finance was provided by the company or $\mathrm{H}$, the debt would qualify under MPA section 20 (7) as one incurred in the course of a common enterprise. Accordingly, $\mathrm{H}$ would not be entitled to an order under section 20(6) for compensation or for an increase in his share of the matrimonial property. In relation to the loan from $\mathrm{H}$, repayment proceeds would qualify as matrimonial property under section $8(\mathrm{e})$.

\section{$D$ Use of a Pre-Existing Entity or Separate Property in Formation of the Business}

\section{Two complicating factors}

The operation of the MPA is complicated in practice by two exogenous factors. First, one of the spouses may control a pre-existing company or partnership which can serve as the vehicle for the business. In some cases, the company or partnership will have been formed before marriage and in other cases after marriage. As the second complicating factor, in many situations, one or both spouses will be able to finance their investment in the business out of separate property. This section explores the ramifications of these two factors. 


\section{The post-marriage company or partnership}

A person in the position of $\mathrm{H}$ in the examples will sometimes, before or during marriage, have been involved in other business ventures. The entities used for those businesses can frequently serve as the vehicle for the new venture.

Example. At the time of the proposed venture, $\mathrm{H}$ already owns all the shares in $\mathrm{H} L t d$, a one person company. As well, $\mathrm{H}$ is an equal partner with $\mathrm{B}$, his brother, in $\mathrm{HB}$ Co, a partnership. Both H Ltd and HB Co were established after $\mathrm{H}$ and $\mathrm{W}$ married. H considers whether the new business should be conducted by the existing company or partnership.

For purposes of the matrimonial property regime, it makes little difference whether $\mathrm{H}$ uses, instead of a newly formed company or partnership, a preexisting but post-marriage entity as the vehicle for the new business. The shares in the preexisting entity are, matrimonial property, as they were acquired after marriage, unless section 9(2) applies. As such, they are subject to the presumptive equal sharing rule in the event of separation. Also, so long as the entity is created after marriage, it makes no difference whether it is created now or many years ago. When the existing company acquires and profitably operates the new assets, this will increase the value of the shares owned by $\mathrm{H}$ and hence the value of W's inchoate matrimonial property. If the existing entity is a partnership, then on its acquisition of the new business assets, the partners will also acquire an equitable (Maw) interest in those new assets which also qualifies as matrimonial property. However, as $\mathrm{W}$ has no legal interest in the shares or contractual control rights over operation of the business assets, the value of her inchoate matrimonial property interest is at risk.

\section{The pre-marriage company}

Different results follow under the MPA where the new venture is conducted by a company created before marriage.

Example. In the previous example, $\mathrm{H}$ considers operating the business through OldH Ltd, a one person company incorporated by $\mathrm{H}$ before his marriage to $\mathrm{W}$.

As the shares were acquired before marriage, they remain identifiable and usually not comingled. Unless they were acquired in contemplation of $\mathrm{H}^{\prime}$ s marriage vow and intended for their common use and benefit and accordingly section 8(d) applies, they do not qualify as matrimonial property but instead remain the separate property of $\mathrm{H}$ after marriage. The acquisition and profitable operation of the assets of the new venture increases the value of those shares. The only relevant matrimonial property is this increase in value and then only if W can establish under section 9(3) that the increase is attributable, wholly or in part, to her actions or the application of matrimonial property. Presumably troubled by the conversion of the entire increase on the basis of a partial contribution, the courts have placed a number of restrictive glosses on section 9(3), for example, in relation 
to the nature of the contribution, measurement of the increase in value, and the causal connection between the increase and the contribution. ${ }^{6}$ However, $\mathrm{W}$ will have a strong argument for conversion where she actively participates in management of the company and/or where the assets were partially financed with matrimonial property including retained earnings otherwise distributable as remuneration. ${ }^{7}$

\section{The pre-marriage partnership}

The results are different again where the pre-marriage entity which acquires the business is a partnership.

Example $[M a w v M a w]$. The new business assets are acquired after marriage by $\mathrm{HB} \mathrm{Co}$, an equal partnership between $\mathrm{H}$ and his brother $\mathrm{B}$ which was established prior to $\mathrm{H}$ 's marriage to W.

As in the company case, H's shares in the partnership are separate property, the value of which is enhanced by the acquisition and operation of the new business after marriage. That increase is matrimonial property but only to the extent that $\mathrm{W}$ can prove that it is attributable, at least in part, to her actions or the application of matrimonial property. However, that is not the end of the matter. Upon transfer of the new assets to the partnership, $\mathrm{H}$ obtained an equitable Maw interest in the property. As that interest was acquired after marriage, it will, unless acquired with the proceeds of separate property, qualify as matrimonial property, half of which may be claimed by $\mathrm{W}$ without regard to her contributions. Where acquisition of the new assets are financed solely through the partnership's premarriage property, H's equitable Maw interest will presumably qualify as separate property relegating W to a claim under MPA section 9(3) or section 17.

\section{The implications of Maw}

The decision in Maw, whilst favourable to $\mathrm{W}$ in the circumstances, undoubtedly led to substitution of the company form for the partnership form as a vehicle for family businesses. A spouse who controls a company registered before marriage would appear positioned to capture, in the event of separation, all the wealth generated by the new business. In the examples, $\mathrm{H}$ would use the old entity as the vehicle for the new business, exclude $\mathrm{W}$ from management and employ no matrimonial property in financing the new venture. However, there are at least three significant limitations on this strategy. First, whilst W's routine involvement in the new business may not count as a contribution under MPA section 9(3), it is recognised for purposes of section 17. Secondly, W's employment in and away from the home will count as a contribution under section 9(3) where it frees $\mathrm{H}$ to

6 Hight $v$ Hight [1997] 3 NZLR 396 (CA).

7 Watson $v$ Watson [1996] NZFLR 673 (CA). 
devote himself to the business. ${ }^{8}$ Thirdly, internally financed gains and increases in value are held to involve an application of matrimonial property for purposes of section 9(3) if funded through retained earnings which would otherwise be distributable as remuneration, that is, as returns to H's service rather than to the pre-marriage capital of the company. ${ }^{9}$

\section{Shares financed from separate property}

In some cases, $\mathrm{W}$ will own separate property which she can use to finance the acquisition of her shares. In this regard, it is necessary to distinguish three types of separate property. The first is property the legal rights in which are vested exclusively in $\mathrm{W}$ but which constitutes matrimonial property in the event of separation. A common example is the savings account in W's name and funded entirely with proceeds of her postmarriage employment. Shares purchased with such property will qualify as matrimonial property in the event of separation. However, as the legal rights to the shares lie exclusively with $\mathrm{W}$, they provide her the control required to protect the value of her inchoate matrimonial property interest. The second type of separate property is property which qualifies as such under the statute, for example, property received by way of gift, succession or proceeds of a trust. This inherited separate property, of which interspousal gifts are a special case, is subject to various rules under the statute. The third type of separate property is property which a spouse holds in the same manner as an unmarried person. This unmarried separate property lies outside the MPA and can coexist with a marriage where provided for by a section 21 agreement. Quite different results follow in the example according to whether the shares are financed with matrimonial separate property or with unmarried separate property. The use of matrimonial separate property is considered below, and unmarried separate property is the subject of the next section.

\section{Financing the venture with matrimonial separate property}

Use of a pre-marriage company as the vehicle for the new venture undermines W's matrimonial property position because the venture's assets become linked to H's separate property. A similar result can occur where matrimonial separate property is used as the source of finance.

Example. H organises the business as H Ltd. H subscribes for all the shares in the company with monies drawn from an account containing only the proceeds of an inheritance.

So long as the funds as well as the shares were not intermingled with matrimonial property, the shares can qualify as separate property. In the event of separation, $\mathrm{W}$ can

8 Hight v Hight [1997] 3 NZLR 396 (CA).

9 Watson $v$ Watson [1996] NZFLR 673 (CA). 
claim as matrimonial property only the increase in value of the shares and then only if she can prove that the increase is attributable, at least in part, to her actions or the application of matrimonial property. By way of contrast, where $\mathrm{H}$ paid for the shares with proceeds of his post-marriage salary or out of family savings, the shares will be matrimonial property subject to the equal sharing rule without regard to W's contribution.

\section{Separate property finance in the partnership}

The legal consequences of financing with matrimonial separate property vary according to whether the venture is organised as a company or partnership.

Example. $\mathrm{H}$ and $\mathrm{W}$ commence business as equal shareholders. $\mathrm{H}$ pays for his shares with $\$ 40,000$, some drawn from the family savings account and the remainder borrowed against the family home. W pays for her shares with $\$ 40,000$ cash funded from her matrimonial separate property. Two years later, when the couple separates, the firm's only asset after payment of creditors is a $\$ 30,000$ credit balance.

The result is straightforward where the firm is company. On liquidation, $\mathrm{W}$ and $\mathrm{H}$ as equal shareholders would each be entitled to $\$ 15,000$. W would retain her liquidation dividend as proceeds of her separate property shares. H's dividend would qualify as matrimonial property subject to the presumptive equal sharing rule. The allocation would, ceteris paribus, be $\$ 22,500$ to $W$ and $\$ 7,500$ to $H$. The result may be different where the firm is a partnership. Each partner has two distinct property interests - their partnership share and their equitable (Maw) interest in partnership assets. Division by reference to the partnership shares leads to the same result as for the company structure. However, in Brenssell $v$ Brenssell ${ }^{10}$ the High Court allowed $W$ to argue for a division by reference to the equitable (Maw) interests. W recovered the entire account balance as proceeds of her initial contribution of separate property. Whilst the claim is subject to the intermingling proviso in section 10(1), this will pose less of a problem where W's contribution was tangible property or, as in Brenssell, the partnership was a short-lived one.

\section{Partner's legal interest in shares as controlling}

The approach in Brenssell is dubious as a matter of both policy and statutory interpretation. Were the partnership in the previous example liquidated without reference to MPA, the liquidating dividend payable to $\mathrm{H}$ and $\mathrm{W}$ would be in proportion to their holdings in the firm, the standard contractual variation of the equal sharing rule in section 27(a) of the Partnership Act 1908. The result would be the same whether the assets were divided in accordance with their partners' shares or their equitable interests, as the former determines the undivided ratios of the latter. For a partner to recover more by tracing

10 [1995] 3 NZLR 320 (HC). 
their initial contribution through the equitable (Maw) interest subverts the agreement as well as the thrust of section 27(a). MPA sections 9(3) and 10(1) should not and need not be read so as to permit a different approach when the liquidation occurs in connection with a division of matrimonial property. Those sections adopt unmodified the common law rule on equitable tracing which has never, to the authors' knowledge, been applied to divide partnership property otherwise than in the proportion associated with the partners' shares. Indeed, the use of tracing seems inconsistent with the undivided nature of the equitable (Maw) interest.

\section{Partnership agreements under section 21.}

Even if read as requiring a different result in the case of matrimonial property disputes, the references to tracing in MPA sections 9(3) and 10(1) apply only insofar as the parties have not agreed otherwise under section 21. The allocation of profits and losses in the partnership agreement can obviously extend to encompass the partners' equitable (Maw) interest in partnership assets. However, this requires that the partnership agreement comply with the formalities required for section 21 agreements, which significantly complicates the use of the partnership form for family businesses.

\section{Brenssell extended to company structures}

The most unsettling ramification of Brenssell concerns its possible application to companies.

Example. $\mathrm{H}$ and $\mathrm{W}$ incorporate $\mathrm{HW} \mathrm{Ltd}$ as equal shareholders. $\mathrm{H}$ contributes a premises which is his separate property. W makes an equal cash contribution from her salary savings. H's dividends are paid into an account under H's name the funds in which are used exclusively for maintaining H's separate property. Neither the business nor the marriage prosper. Three years later, $\mathrm{H}$ and $\mathrm{W}$ separate and the company is liquidated. After payment of debts, the premises is the company's only remaining asset which has a liquidation value of $\$ 100,000$.

Apart from a division under the MPA, $\mathrm{H}$ and $\mathrm{W}$ would each be entitled to a liquidating dividend of $\$ 50,000$, that is, reflecting their equal holdings in the company. For purposes of the MPA, H's shares arguably qualify as separate property under MPA section 9(2) [the common use exception under section 8 being negated by disposition of the dividends] as does the liquidating dividend as identifiable proceeds of the shares. W's shares are matrimonial property, as is the liquidating dividend paid on those shares. Accordingly, $\mathrm{H}$ would be presumptively entitled to $\$ 75,000$ and $W$ presumptively entitled to $\$ 25,000$. Having read Brenssell, however, $\mathrm{H}$ may seek to claim the premises in its entirety as separate property. The claim is weaker than the comparable one in Brenssell. The Brenssell result rests heavily on the partner's residual equitable interest in partnership assets. In contrast, when $\mathrm{H}$ transfers the premises to the company as consideration for shares, the 
company becomes entitled to all the legal and beneficial interests in the property. To the authors' knowledge, the tracing rules have never been applied to entitle a shareholder to a greater dividend than that payable under the terms of their shares. A contrary result would clash severely with the statutory rights associated with company shares under CA section 36 .

\section{Planning implications of Maw and Brenssell.}

Until the matter is resolved by the courts or Parliament, the decisions in Maw and Brenssell unsettle the operation of partnership agreements. Whenever possible, advisers should probably avoid use of the partnership form in favour of the corporate form. There remain few instances, after changes in the tax legislation, where the corporate form cannot be employed instead of the partnership form. Where the partnership form is employed as between spouses, the agreement should expressly address and specify the ratio of the partners' equitable (Maw) interests which, in most all cases, should follow the ratio of the partners' shares in the profits and losses of business. The agreement should identify itself as one under MPA section 21 for the purpose of contracting out of any result which might otherwise follow under MPA ss 9(3) and 10(1). While the requirement for separate advice is burdensome, it is appropriate even in the absence of section 21.

\section{E Unmarried Separate Property}

\section{MPA unsuitable for some family structures.}

The MPA reflects and promotes a family structure in which one spouse is employed outside the home and other manages the household and cares for the children. It is less suitable in the increasingly common situation where both spouses are employed outside the home and third persons tend to the children and household.

Example. $\mathrm{H}$ and $\mathrm{W}$ are both employed. Each owns investments worth $\$ 100,000$ financed by

salary savings. H starts a business with $\$ 40,000$ funded from his savings.

In the traditional family structure, where $W$ has no own property, $\mathrm{H}^{\prime}$ s action puts at risk W's inchoate matrimonial property interest. In the example, H's action puts at risk not only this expectancy but also W's legal entitlement to her own property. Suppose that, six months after commencement of the business, the couple separates and the venture fails without returning any profit or capital. The presumptive equal division of matrimonial property under the MPA requires that $W$ transfer $\$ 20,000$ of her assets to $H$. The statutory regime shifts to $\mathrm{W}$, without any consent on her part, half the actual loss resulting from $\mathrm{H}$ 's investment of his own property. Further, the extent of the loss depends upon management of the investment, a matter over which $\mathrm{W}$ has no formal control unless she takes up shares and/or a position on the board. However, this requires an investment of funds and/or exposes her to liability as a director of the company. 


\section{The property regime for the unmarried couple}

W's position in the above example changes dramatically if she and $\mathrm{H}$ are not married. H's investment of his own funds does not put W's property at risk. If the business fails and the couple separates, each party will retain intact their investment portfolios. The financial consequences of the failed venture will be visited on $\mathrm{H}$ alone. If $\mathrm{W}$ does decide to participate in the new business, the extent of her risk will be congruent with her investment and within her control. Where parties to a relationship have their own investments and livelihood, one or both may view the property regime for unmarried persons as providing better protection than the statutory scheme for married couples.

\section{Separate property under the MPA.}

Whilst the MPA recognises separate property, this property [statutory separate property] is subject to rules which currently have no counterpart in relation to the property of unmarried (in a legal or defacto sense) spouses [unmarried separate property]:

- An increase in the value of statutory separate property and any income or gains from such property are matrimonial property if attributable, wholly or partially, to the actions of $\mathrm{H}$ or the application of matrimonial property [MPA section 9(3)].

- Statutory separate property acquired by succession or gift can become matrimonial property if it is intermingled with other matrimonial property or used for the benefit of both spouses [section 10].

- If statutory separate property is sustained by the application of matrimonial property or the actions of one spouse, the Court may increase the other spouse's share of the matrimonial property or order compensation [section 17(1)].

- If statutory separate property has been materially diminished in value by deliberate action of one spouse, the Court may diminish the other spouse's share in the matrimonial property or order compensation [section 17(2)].

These rules make a person's entitlement to their statutory separate property far more tenuous than their entitlement to unmarried separate property.

\section{Differences illustrated}

The differences between statutory and unmarried separate property are significant in even the most basic business scenarios.

Example. $\mathrm{H}$ and $\mathrm{W}$ initiate a venture in the form of an equal two person company. W pays for her shares with $\$ 20,000$ taken from a trust account funded by an inheritance. By the time the parties separate, the company's net assets have, under H's management, increased from $\$ 40,000$ to $\$ 100,000$, remained unchanged at $\$ 40,000$ or fallen to zero. 
If $\mathrm{H}$ and $\mathrm{W}$ are not married, $\mathrm{W}$ 's holding entitles her to a liquidating dividend of $\$ 50,000$, $\$ 20,000$ and zero respectively in the three cases. In a given situation, the amount of the distributions to $\mathrm{H}$ and $\mathrm{W}$ depends on the allocation of shares and not on whether $\mathrm{H}$ was particularly diligent or derelict in his role as manager. If $\mathrm{H}$ and $\mathrm{W}$ are married, $\mathrm{W}$ 's shares will qualify as statutory separate property. Where the value of W's shares has risen to $\$ 50,000$, the increase will be matrimonial property if attributable, wholly or in part, to the actions $\mathrm{H}$ or to the application of matrimonial property. Any nontrivial contribution, for example, by the actions of $\mathrm{H}$ as manager or by reinvestment of retained earnings, may suffice to convert the entire increase $[\$ 30,000]$ into matrimonial property. Under section $15, \mathrm{H}$ is presumptively entitled to one half the increase in value of W's shares and may claim a larger proportion on grounds of his role in management. Even where the increase cannot be attributed to H's actions or the application of matrimonial property, $\mathrm{H}$ can claim a greater share of the matrimonial property or compensation under section 17 . The situation is quite different where there has been a decrease in the value of W's shares due to $\mathrm{H}$ 's bad management. Under section $17, \mathrm{~W}$ is entitled to relief, either by way of a larger share of the matrimonial property or a compensatory order, but only if the decrease is a material one and results from deliberate conduct by $\mathrm{H}$. Finally, where the value of the shares remains unchanged in value, $\mathrm{W}$ is not necessarily entitled to their full value in the event of separation. H can claim compensation under section 17 or an increased share of the matrimonial property under section 18. Both commentators and the courts have criticised the regulation of matrimonial separate property as inconsistent with other features of the statutory regime. ${ }^{11}$ However, the linkage between matrimonial and statutory separate property as well as the unequal allocation of upside and downsize risks seems arguably appropriate for the traditional family structure where the family's wealth is owned and managed by one spouse.

\section{Unmarried separate property regime as superior.}

Where one spouse is concerned to maximise control over their property, the spouse is, in at least two respects, better served by the regime for unmarried separate property than the regime for matrimonial property and statutory separate property. First, unmarried separate property is immune from the sort of involuntary investment illustrated by the penultimate example. Secondly, as illustrated by the previous example, once the spouse has decided to invest, the spouse can better capture increases in value of an investment funded by unmarried separate property than one funded by statutory separate property. These advantages are not a concern in the traditional family structure where ownership and management of family wealth is the responsibility of only one of the spouses.

11 Hight $v$ Hight [1997] 3 NZLR 396 (CA). See Hon R C Fisher (ed) Fisher on Matrimonial Property (Butterworths, Wellington, 1998) (updated 1999) para 11.39. 


\section{Unmarried separate property under a section 21 agreement}

A married spouse can access the regime for unmarried separate property by contracting out of the MPA under section 21 providing the other spouse agrees to such a course of action. If made before marriage, such an agreement is expressly authorised by section 21(1). After marriage, the agreement can be made under section 21(2) for the purpose of settling any differences that have arisen between the spouses concerning the property owned by either or both of them. Whilst section 21(2) obviously anticipates the usual property agreement upon separation, there is no reason why it cannot serve as the basis of a post-marriage, pre-separation agreement. The difference concerning property required by the section can be found, for example, in relation to the rule in section 19(1) that matrimonial property owned by one spouse can be disposed of by that spouse without the consent of the other spouse. The spouse owning the property will favour this rule while the other spouse will oppose it. The agreement itself poses no peculiar problems for the drafter particularly when put in place before marriage. The agreement will provide that the parties contract out of the Act and shall be treated as unmarried persons in relation to all matters respecting ownership of property during marriage and in the event of separation. The agreement may elaborate on this by expressly stating that each spouse shall acquire rights in the property of the other spouse only by way of purchase, devise or gift as would apply if the parties were not married. Where concluded after marriage, the agreement will contain similar provisions but must also make provision for property which has already become matrimonial property. The drafter must take care that references to separate property distinguish, as necessary, between the matrimonial and statutory variants.

\section{F Conclusion}

There are two principal lessons that emerge from this introductory study of family business interests under the matrimonial property and companies legislation. The first concerns operational interdependence. As applied to family ventures, the business entities legislation, with its ample allowance for contractual autonomy, provides a extensive flexibility. For every important event in the life of a business there are several transactional options. Each alternative has its unique ramifications under the matrimonial property legislation which, in most all cases, differ significantly from the result under the property regime for unmarried persons. The interrelationship of events within and between the business entity and marriage gives the nexus a temporal and substantive extent comparable to that existing between tax law and company law.

The second lesson concerns the unsuitability of the matrimonial property regime for family structures involving a business operation. On the one hand, the interposition of a business entity between owners and assets greatly obfuscates application of the MPA. Coupled with the inherent transactional complexity, this creates an impediment to 
planning and dispute resolution which, judging from the volume and substance of the cases, may be without parallel in contemporary New Zealand civil law. On the other hand, the MPA was designed for marriage relationships quite different from those associated with today's family businesses. The statute and the proposed similar regime for de facto property (De Facto Relationships Property Bill) lead to results which will be unacceptable to spouses concerned with parity in control and financial independence. Fortunately, there is a single solution to both difficulties. The current regime for unmarried separate property, accessible by a MPA section 21 agreement, operates in a far more predictable manner and better suits the interests of many spouses. 